\title{
Flowering, fruiting and physiology of apple tree under different irrigation levels in the Brazilian semiarid region
}

\author{
Cíntia Patrícia Martins de Oliveira', Welson Lima Simões², José Aliçandro Bezerra da Silva ${ }^{3}$, \\ Paulo Roberto Coelho Lopes², Emanoel Fernando Jurema Araújo4, Bruna Lais da Silva Cavalcante ${ }^{4}$ \\ 'Universidade Federal do Vale do São Francisco, Juazeiro, BA, Brazil \\ 2Embrapa Semiárido, Petrolina, PE, Brazi \\ ${ }^{3}$ Universidade Federal do Vale do São Francisco, Juazeiro, BA, Brazil \\ 4Universidade de Pernambuco, Petrolina, PE, Brazil \\ *Autor correspondente, e-mail:
}

\begin{abstract}
The objective of this study was to evaluate the effect of different irrigation levels on flowering, fruit set, carbohydrate and protein content and gas exchange, of apple varietiesin the Brazilian semiarid region. The experimental design was a randomized block with split plots with five replications and four plot irrigation levels $(60,80,100$, and $120 \%$ of the reference evapotranspiration (ETo)) and the subplots with two cultivars (Juliet and Princess). As a result, it was found that the number of flowers (NFL), fruits (NFR), shoot percentage (SP) and fruit set (FS) were higher in cv. Juliet. The number of buds (NB) and the fertility index (FI) were higher in cv. Princess. With regard to metabolites, reducing sugar content (RS) had no significant effect among cultivars. The non-reducing sugar content (NRS), total soluble sugar (TSS) and total soluble proteins (TSP) were higher in cv. Princess. As for irrigation depths, TSP, sprouting, flowering and fruit set increased along with the amount of water applied, while the RS, NRS and TSS contents had the opposite behavior.
\end{abstract}

Keywords: water regime, Malus domestica, reproductive organs, metabolites

\section{Resumo}

O objetivo deste trabalho foi avaliar o efeito de diferentes lâminas de irrigação na floração, frutificação efetiva, teores de carboidratos e proteínas e nas trocas gasosas de duas cultivares de macieira no semiárido brasileiro. O delineamento experimental foi em blocos ao acaso, com parcelas subdivididas, com cinco repetições, sendo as parcelas quatro lâminas de irrigação (60; 80; 100; e 120 \% da evapotranspiração de referência (ETo) e as subparcelas duas cultivares (Julieta e Princesa). Como resultado verificou-se que o número de flores (NFL), de frutos (NFR), a porcentagem de brotações (PB) e a frutificação efetiva (FR) foram superiores na cv. Julieta, enquanto o número de gemas (NG) e o índice de fertilidade (IF) foram superiores na cv. Princesa. Quanto aos metabólitos, o teor de açúcar redutor (AR) não apresentou efeito significativo entre as cultivares, sendo o teor de açúcar não reduto (ANR), açúcar solúvel total (AST) e o total de proteínas solúveis (TPS) superior na cv. Princesa. Quanto às lâminas de irrigação, o TPS, a brotação, a floração e a frutificação efetiva aumentaram juntamente com a quantidade de água aplicada, enquanto que o teor de AR, ANR, AST, apresentaram comportamento oposto

Palavras-chave: Regime hídrico, Malus domestica, órgãos reprodutivos, metabólitos 


\section{Introduction}

The apple tree (Malus domestica Borkh) is a crop with great socio-economic importance throughout the world, and in Brazil it is one of the principal temperate fruit trees grown, with $98 \%$ of national production located in the southern region (IBGE, 2014). However, fruit farming is expanding to non-traditional areas for temperate climate fruit crops (Lopes et al., 2013a; Miranda et al. 2015a and 2015b).

According to Iuchi (2006) to obtain satisfactory sprouting and flowering of apple trees in regions of low cold incidence, the use of cultivars with low chill hour requirements is required. According to Lopes et al. (2013b) the apple cultivars 'Princess' and 'Juliet' have, respectively, chill hour requirements of approximately 350 to 450 and 300 to 450 for breaking natural dormancy. These varieties have shown good results in the state of Ceara, both in the floral differentiation, and in flowering, fruiting and fruit quality (Lopes et al., 2013b).

The flowering, pollination and fruit set are the most critical phenological phases of apple (Cardoso, 2011), since yield components are determined in these periods. Prado et al. (2007) observed that water management affects the flowering, growth and the formation of reserves in fruit trees.

Peixoto et al. (2006) state that the study of plant water relationships and interactions caused by water deficit on physiological processes are of fundamental importance to obtain a good irrigated crop, especially in semi-arid regions. Garcia-Tejero et al. (2011) observed that in fruit trees grown in a semi-arid Mediterranean climate the application of sustained- deficit irrigation offers promising possibilities for crop irrigation optimization and increased water productivity in the orchard.

Furthermore, Ribeiro et al. (2013) report that the plants under water deficit present alterations, such as reductions in transpiration, stomatal conductance, photosynthesis, carbon metabolism enzyme activity modification and changes in antioxidant levels. However, the carbohydrates accumulated in plant roots, branches and leaves make up an important source of carbohydrates during flowering and in early stages flower and fruit formation and development (Cruz et al., 2007).

Thus, in view of the apple cultivation potential in the semiarid and the sacrcity of information to aid efficient crop irrigation management in the region, this study aimed to evaluate the effect of different irrigation levels on flowering, fruit set, carbohydrate and protein content and gas exchange of apple trees (Julieta and Princess cultivars) under the conditions of the Brazilian semiarid region.

\section{Material and Methods}

The experiment was conducted in an experimental orchard on the Corcino Frutas farm, located in the Perímetro Irrigado Senador Nilo Coelho, Núcleo 5, Petrolina - PE, between October and December 2014. The study was conducted with two-year-old Malus domestica apple trees, propagated by grafting (Maruba rootstock with $M 9$ interstock filter), grown at $4.0 \mathrm{x}$ $1.25 \mathrm{~m}$ spacing.

The work was conducted in a randomized block experimental design with five replications and ten plants per plot. The treatments were arranged in split plots. The plots were the four water depths $(60,80,100$ and $120 \%$ of the reference evapotranspiration (ETo), and the subplots were the varieties Juliet and Princess.

The irrigation system used was two drip lines, with emitter flow rate of $2.1 \mathrm{I} \mathrm{h}^{-1}$, with daily watering shifts. The irrigations were based on ETo calculated by Penman-Monteith method from climatic data collected at the weather station located near the site of the experiment.

The weather data recorded during the experiment are in Figure 1.

The evaluations began at the beginning for the bud swelling period. In each plot we selected two branches, at the average height of the canopy exposed to the sun, and the evaluations made from the apex to a length of $35 \mathrm{~cm}$ along the branch.

We evaluated the fertility index from the direct relationship between the number of flowering buds and the length of the branches, expressed in number of flowering buds per centimeter of branch, as well as the average flowering bud count, average of flowers and 
fruits, the sprouted bud percentage and fruit set (obtained from the relationship between the number of fruits and number of flower clusters counted during full bloom, expressed as a percentage) based on the methodology of Tomaz et al. (2010).

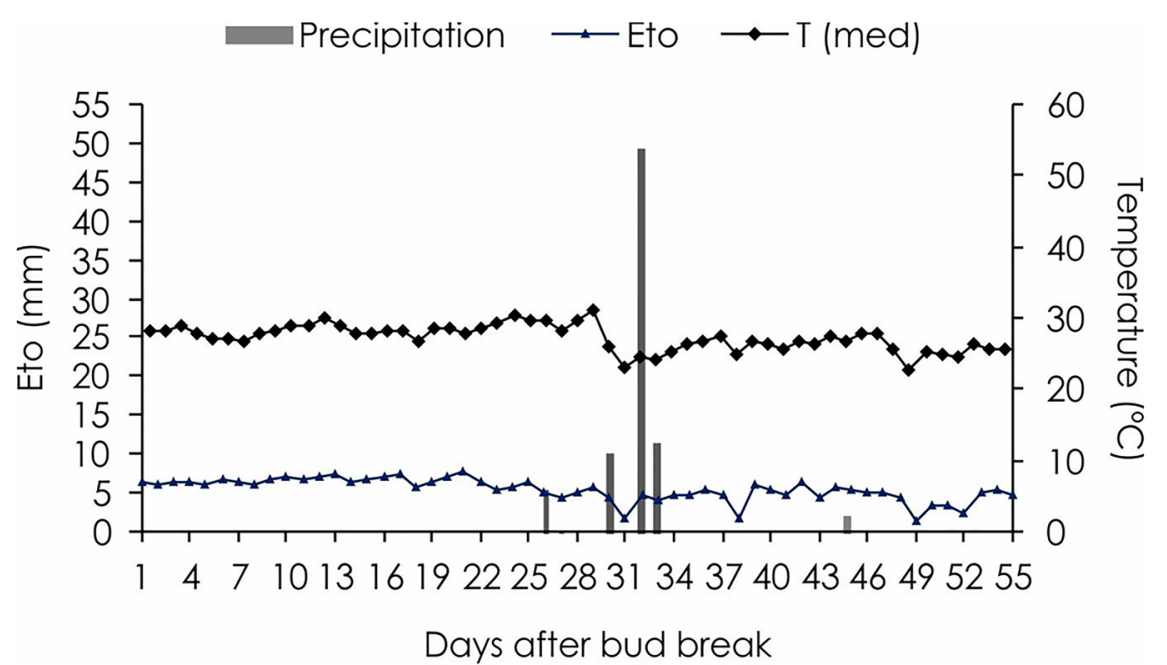

Figure 1. Average temperature (T), reference evapotranspiration (ETO) and precipitation values during the trial period, equivalent to 55 days after bud break (DABB) starting from October, 2014.

We evaluated gas exchange 29 days after bud break, with specific individual measurements, between 8 and 10 a.m. in fully expanded and fully formed leaves. Readings were taken using a gas exchange measuring device (IRGA - Li Licor® 6400). Measurements were taken of leaf temperature, net photosynthetic rate (A), transpiration (E), stomatal conductance $\left(g_{s}\right)$, internal $\mathrm{CO}_{2}$ concentration (Ci) and photosynthetically active radiation (PAR). With the gas exchange data we determined the instantaneous water-use efficiency $\left(\mathrm{W} \mathrm{E}^{-1}\right)$ and the intrinsic water use efficiency (W $\mathrm{gs}^{-1}$ ).

To determine carbohydrate and protein content 22 days after bud swelling we selected and collected fully expanded leaves of spur branches most exposed to sunlight, healthy leaves with no signs of senescence. The leaves were immediately immersed in liquid nitrogen, bagged, identified according to their origin and stored in a freezer with at $-20^{\circ} \mathrm{C}$ until biochemical analysis.

We evaluated the leaf content of reducing sugars, quantified by the dinitrosalicylic acid (DNS) colorimetric method - DNS, which quantifies glucose, fructose and mannose in plant tissues (Miller, 1959); total soluble sugars, according to the methodology described by Yemm \& Willis (1954); and proteins following the method described by Bradford (1976) using bovine serum albumin as the standard protein (BSA, Sigma, USA). Having the reducing sugars and total soluble sugars data we estimated the non-reducing sugar content.

Data were submitted to analysis of variance, comparison of means by the Tukey test at $5 \%$ probability and when significant to the irrigation levels, regression analysis to a $5 \%$ probability level, using the Sisvar statistical program.

\section{Results and Discussion}

According to the results there was no significant effect of the irrigation level/ cultivar interaction that can be observed in Table 1.

However, in this study, we observed an isolated effect of irrigation levels. Based on regression analysis for variables (Tf), (PAR), (A), (E) and $\left(g_{s}\right)$, the linear model was the best fit, the other variables did not show an adjustable model.

Figure 2 contains the data for the apple tree flowering period, individualizing the effects of the levels on the gas exchange determinants.

For photosynthetic activity evaluation, considering the two cultivars, it appears that increasing the irrigation level provided a small increase in stomatal conductance, photosynthetic activity and transpiration. This 
fact probably occurred because of the higher soil surrounding the root system (Kobayashi et al., water availability due to increased moisture in 2008).

Table 1. Mean squares and significance test for variables photosynthesis (A), transpiration (E); stomatal conductance $\left(g_{s}\right)$; internal $\mathrm{CO}_{2}$ concentration (Ci); leaf temperature $\left(\mathrm{T}_{\mathrm{f}}\right)$; Instant water use efficiency $\left(\mathrm{W} \mathrm{E}^{-1}\right)$; Intrinsic water use efficiency ( $\mathrm{W} \mathrm{g} \mathrm{g}_{s}^{-1}$ ) and photosynthetically active radiation (PAR).

\begin{tabular}{|c|c|c|c|c|c|c|c|c|c|}
\hline S.V. & DF & A & $E$ & $g_{s}$ & $C_{i}$ & $\mathrm{~T}_{\mathrm{F}}$ & $W E^{-1}$ & $\mathrm{~W} \mathrm{~g}_{\mathrm{s}}^{-1}$ & PAR \\
\hline Block & 4 & $18.70^{\text {ns }}$ & $4.43^{\text {ns }}$ & $0.02^{\text {ns }}$ & $90.33^{\text {ns }}$ & $0.40^{\text {ns }}$ & $0.02^{n s}$ & $31.93^{\text {ns }}$ & $37999.23^{\text {ns }}$ \\
\hline Level(L) & 3 & $30.61^{\mathrm{ns}}$ & $7.26^{\text {ns }}$ & $0.03^{\text {ns }}$ & $68.57^{\mathrm{ns}}$ & $1.00^{\text {ns }}$ & $0.01^{\mathrm{ns}}$ & $44.81^{\text {ns }}$ & $20778.90^{n s}$ \\
\hline Residue (L) & 12 & 19.52 & 3.94 & 0.01 & 96.18 & 0.39 & 0.06 & 27.05 & 22621.29 \\
\hline Cultivar (C) & 1 & $0.15^{\mathrm{ns}}$ & $0.01^{\mathrm{ns}}$ & $0.00^{\text {ns }}$ & $0.32^{\text {ns }}$ & $1.06^{*}$ & $0.00^{\text {ns }}$ & $7.39^{n s}$ & $1728.57^{n s}$ \\
\hline$L \times V$ & 3 & $2.56^{\mathrm{ns}}$ & $3.41^{\mathrm{ns}}$ & $0.00^{\text {ns }}$ & $6.39^{\text {ns }}$ & $0.18^{\text {ns }}$ & $0.56^{\text {ns }}$ & $24.26^{\text {ns }}$ & $11719.21^{\mathrm{ns}}$ \\
\hline Residue (C) & 16 & 10.71 & 1.38 & 0.01 & 127.33 & 0.17 & 0.64 & 29.71 & 14673.59 \\
\hline$C V-L(\%)$ & - & 26.09 & 19.67 & 25.11 & 5.06 & 1.67 & 15.32 & 13.87 & 8.46 \\
\hline$C V-V(\%)$ & - & 19.93 & 11.64 & 22.59 & 4.51 & 1.12 & 15.12 & 14.54 & 6.81 \\
\hline Mean & & 16.93 & 10.09 & 0.46 & 252.99 & 12.72 & 1.67 & 37.5 & 1777.76 \\
\hline
\end{tabular}

Means followed by the same letters do not differ by the $\mathrm{F}$ test at $5 \%$ probability.
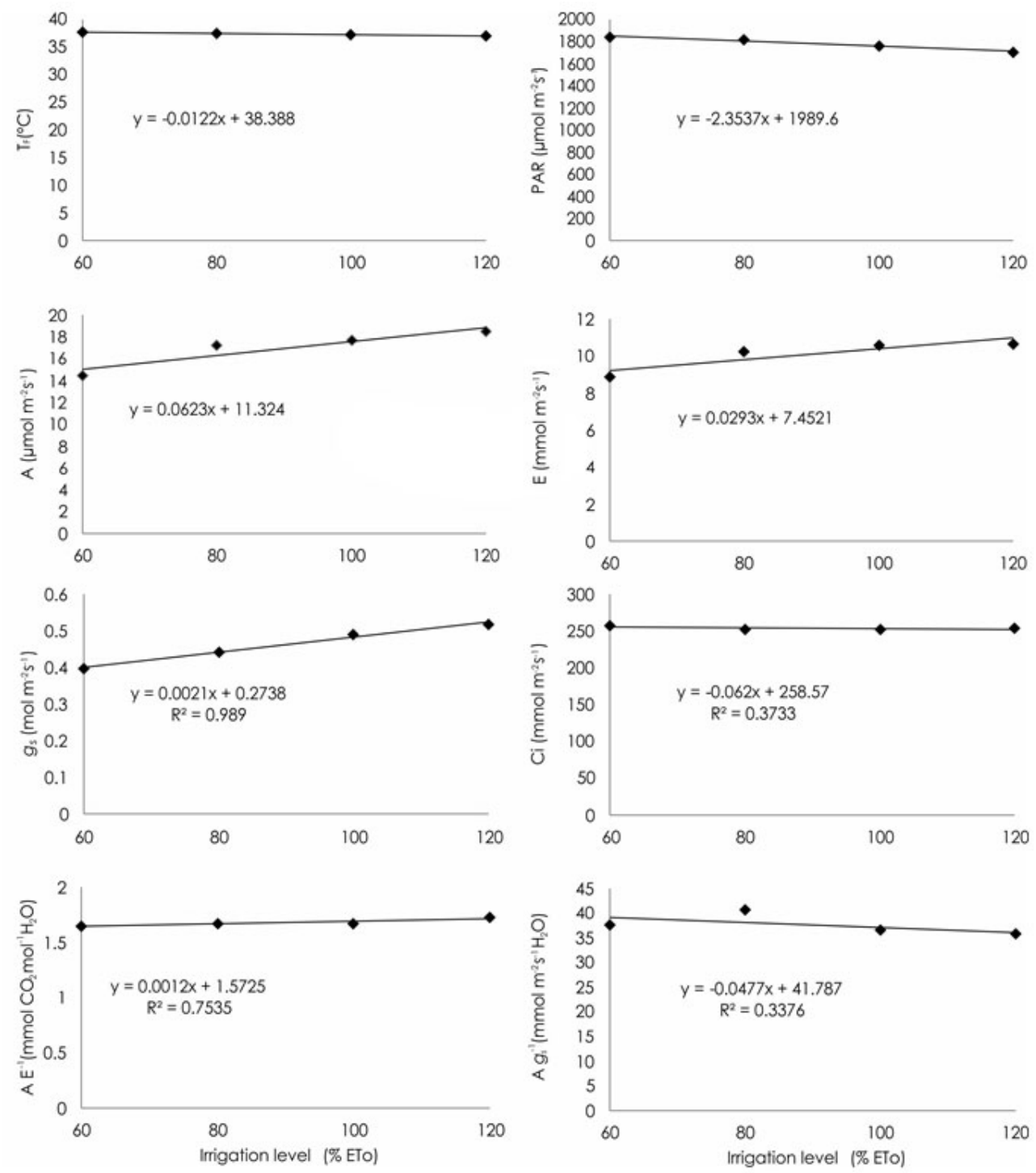

Figure 2. Irrigation level effect on: A - leaf temperature $\left(T_{f}\right) ; B$ - photosynthetically active radiation (PAR); C photosynthesis (A), D transpiration $(E)$; stomatal conductance $\left(g_{s}\right)$; $F$ - internal $\mathrm{CO}_{2}$ concentration (Ci); $\mathrm{G}$ - instantaneous water use efficiency $\left(W E^{-1}\right) ; H$ - intrinsic water use efficiency $\left(W g_{s}^{-1}\right)$ in apple tree leaves, submitted to different irrigation levels. 
One hypothesis that could explain the fact that the gas exchange in apple was not influenced by different irrigation levels imposed during the evaluation date, would be the fact that there was $6.0 \mathrm{~mm}$ of rain three days before sampling, a fact that may have influenced the water availability for the plant between treatments, inspite of having evapotranspiration of $20.1 \mathrm{~mm}$ in this period. Another fact is that the momentary gas exchange measurements may not reflect the true plant physiological behavior under stress condition throughout the day and therefore they need to be assessed with some caution (Silva et al., 2013).

In this context Taiz \& Zeiger (2013), report that along the natural course of the day there is an unbalance between the water absorbed by the root system and that transpirated through the leaves, regardless of the water supply condition, depending on the oscillation of the atmospheric evaporative demand throughout the day. Thus, it is possible that at any time of day significant differences can be detected among irrigation deficit treatments, since the readings were taken only during the morning (Silva et al., 2013) and evapotranspiration demand at this time in the study area is quite high.

Another hypothesis that probably contributed to the variables correlated with the photosynthetic activity not presenting significant alterations may have been the fact that during the evaluation period the apple trees were using the reserves accumulated in the vegetative stage for the initial development of the reproductive organs. This could be beacuse the initial development of apple leaf area is due to carbon stocks and nutrients stored in the plant during previous cycles (luchi, 2006).

Table 2 shows the comparison between apple tree cultivars and gas exchange determining parameters. When precisely comparing cultivars in relation to photosynthetic activity, only the leaf temperature showed significant differences. When measure between 8 a.m. to 10 a.m, there was a difference of approximately $0.18^{\circ} \mathrm{C}$. However, this difference did not affect the leaf photosynthetic process.

Table 2. Photosynthesis (A), transpiration (E), stomatal conductance $\left(g_{s}\right)$, internal $\mathrm{CO}_{2}$ concentration (Ci), leaf temperature $\left(T_{f}\right)$, instantaneous water use efficiency $\left(\mathrm{W} \mathrm{E}^{-1}\right)$ and intrinsic water use efficiency $\left(\mathrm{W}_{\mathrm{s}}^{-1}\right)$; in leaves of two apple tree cultivars submitted to different irrigation levels.

\begin{tabular}{ccccccccc}
\hline & $\mathrm{A}$ & $\mathrm{E}$ & $\mathrm{g}_{s}$ & $\mathrm{C}_{\mathrm{i}}$ & $\mathrm{T}_{\mathrm{f}}$ & $\mathrm{PAR}$ & $\mathrm{W} \mathrm{E}^{-1}$ & $\mathrm{Wg}_{s}^{-1}$ \\
\hline Juliet & $16.9 \mathrm{a}$ & $10.1 \mathrm{a}$ & $0.45 \mathrm{a}$ & $252.9 \mathrm{a}$ & $37.5 \mathrm{a}$ & $1784.3 \mathrm{a}$ & $1.7 \mathrm{a}$ & $37.9 \mathrm{a}$ \\
Princess & $17.0 \mathrm{a}$ & $10.1 \mathrm{a}$ & $0.47 \mathrm{a}$ & $253.1 \mathrm{a}$ & $37.1 \mathrm{~b}$ & $1771.2 \mathrm{a}$ & $1.7 \mathrm{a}$ & $37.1 \mathrm{a}$ \\
\hline $\mathrm{CV} \%$ & 19.93 & 11.64 & 22.59 & 4.51 & 1.12 & 6.81 & 15.12 & 14.54 \\
\hline \multicolumn{2}{l}{ Means followed by the same letters do not differ by the F fest at 5\% probability. }
\end{tabular}

Alizadeh et al. (2011) evaluated the effects of water stress on the physiology of different apple rootstocks in arid conditions of Iran, and observed an increase in leaf temperature with increasing stress levels. According to these authors the leaf temperature difference, depending on the cultivar, is indicative of leaf drought tolerance differences.

As for the results for the leaf biochemical analysis, Figure 3 presents the averages of the variables evaluated for the factor cultivar, in which only the reducing sugar variable (RS) had no significant effect.

In the present study the highest TSS content in the leaves was in the $\mathrm{cv}$. Princess with a concentration of $1700.6 \mathrm{mg} \mathrm{g}^{-1}$ differing from cv. Juliet, that presented $1234.9 \mathrm{mg} \mathrm{g}^{-1}$.
Regarding NRS, cv. Princess also presented higher levels (1347 $\mathrm{mg} \mathrm{g}^{-1}$ ) when compared with $\mathrm{cv}$. Juliet (865.3 $\left.\mathrm{mg} \mathrm{g}^{-1}\right)$.

Borba et al. (2005) observed two distinct periods in carbohydrate flow in the roots of Rosaceae family fruit grown in a tropical climate. The first flow, with carbohydrate accumulation in the roots, occurred in the period after harvest until leaf fall (dormancy). The second carbohydrate flow of was at the beginning of the production cycle, with the mobilization of the reserves from the roots to the crown.

Thus, the increase in leaf carbohydrate levels observed in this study may be due to the mobilization of the reserves from the roots to the crown. These reserves were used in the initial growth of reproductive organs, since soon 
after flowering of various fruit species, demand for assimilates increases their drain and the carbohydrate reserves (starch) are converted to soluble sugars available for use in fruit establishment and setting (Prado et al., 2007 ).

As for foliar TSP there was a significant difference between the apple tree cultivars under different water regimes. According to Kala \& Godora (2011), the protein content may decrease the action of proteases or proteolysis, due to the water availability reduction.
Furthermore, the consumption or production of proteins is related to gene expression of each species, a factor crucial to stress recovery in a manner less costly to plant growth maintenance and development (Santos et al., 2013).

The RS, NRS, TSS and TSP variables also showed significant effects regarding the irrigation levels applied and according to regression analysis, the linear model was the best fit (Figure 4).

\section{- JULIETA $\square$ PRINCESA}

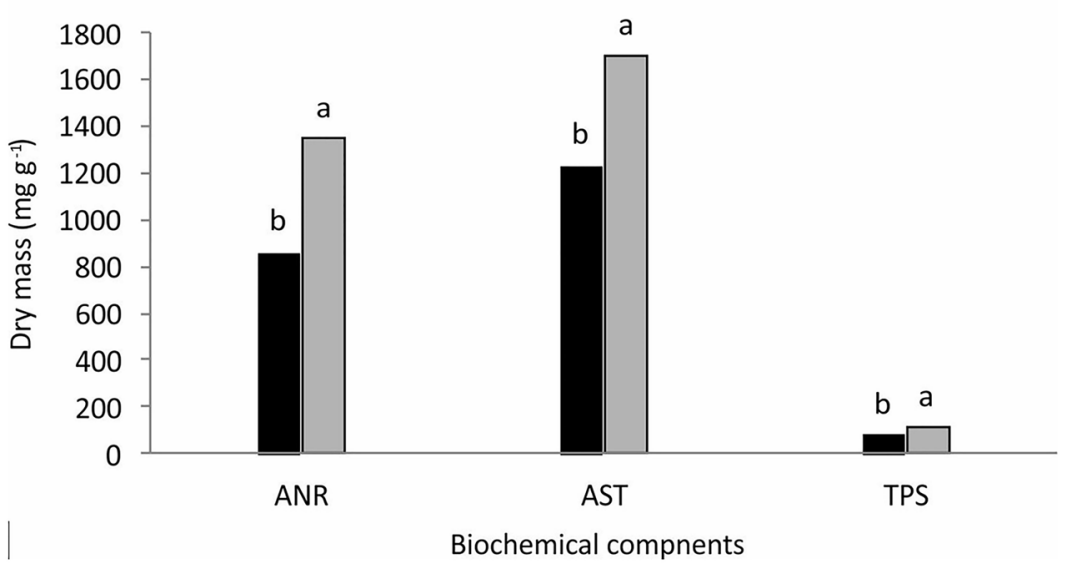

Figure 3. Non reducing sugars (NRS), total soluble sugars (TSS) and total soluble protein (TSP) in the leaves of apple tree cultivars Juliet and Princess, during flowering.
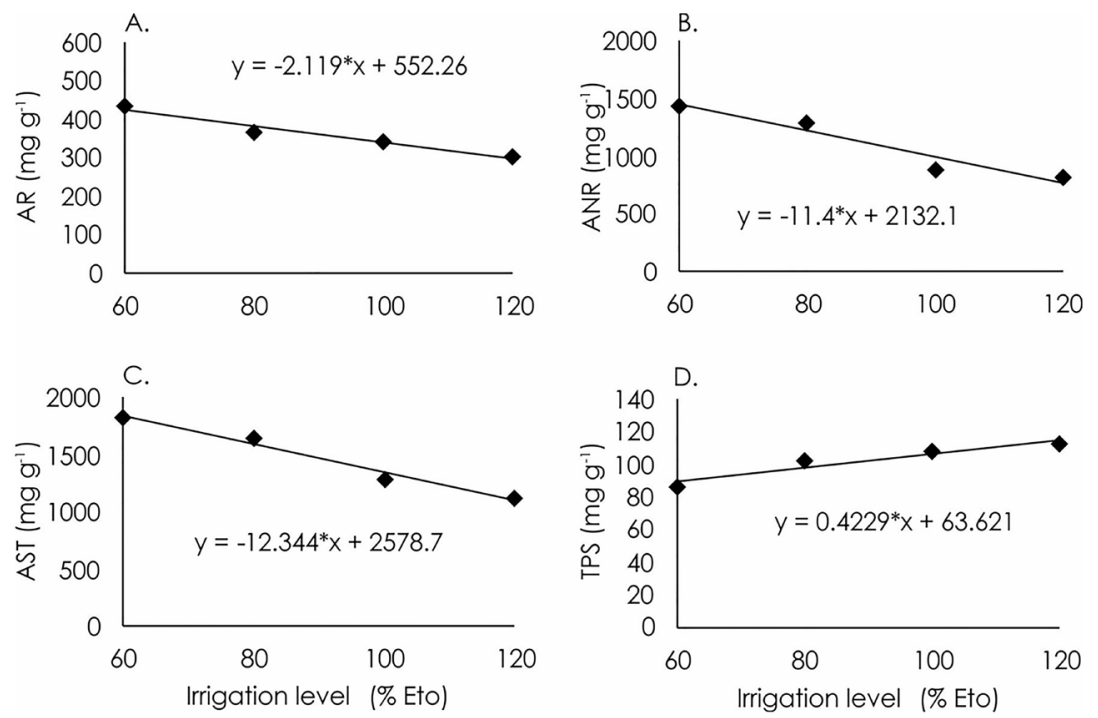

Figure 4. Reducing Sugars (RS), Non Reducings Sugars (NRS), Total Soluble Sugars (TSS), Total Soluble Proteins (TSP) of apple trees submitted to different irrigation levels during flowering.

Plants under different irrigation levels showed a gradual increase in the RS (Figure 4A), NRS (Figure 4B) and TSS (Figure 4C) leaf concentrations as irrigation levels reduced. Alterations in carbohydrate levels were also detected in apple trees when they were exposed to irrigation levels with less water availability (Šircelj et al., 2007, Sivaci, 2006).

According to Costa et al. (2008), water deficiency is characterized by the loss of water which exceeds the absorption rate and thus acts directly on plant water relationships. 
Plant damage depends on the intensity and exposure period, subsequently, promoting cell alterations and changes in molecular pathways. Accumulation of organic solutes such as carbohydrates and proline is also reported.

According to Oliveira et al. (2013a) reducing sugars, such as glucose, are usually used by plants to carry out their metabolic functions, as well as for formation and emission of vegetative and flowering shoots.

Furthermore, a progressive increase in the total amount of soluble carbohydrates, such as sorbitol, sucrose and starch in the cells, improves plant resistance, this effect is characterized as crop adaptation to drought and has been studied in several cultivars (Fioreze et al. 2011).

For foliar TSP levels, a linear reduction was
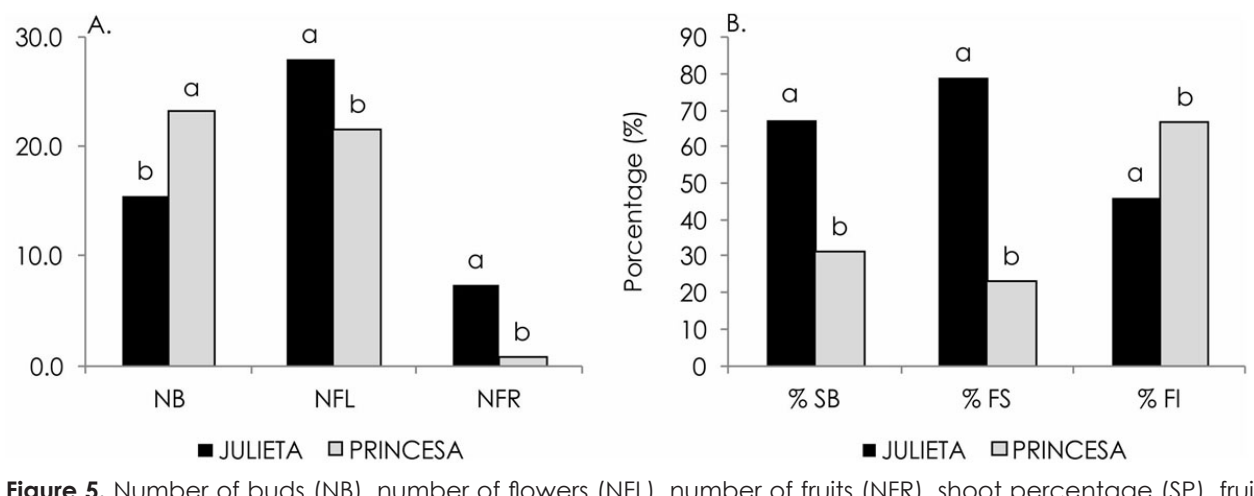

Figure 5. Number of buds (NB), number of flowers (NFL), number of fruits (NFR), shoot percentage (SP), fruit set (FS) and fertility index (FI) in two apple tree cultivars grown under a semiarid climate.

In Figure 5A, cv. Juliet showed the best result for flower setting and their transformations into fruits, differing from cv. Princess. This behavior may be associated with intrinsic factors for each cultivar. According to Lopes et al. (2013a) it is common for the first apple harvest to be low under Brazilian semiarid conditions.

The $c v$. Princess, even with the highest fertility rate and number of buds per branch, presented a lower number of flowers compared to $\mathrm{cv}$. Juliet, demonstrating the specificity among cultivars.

In addition to the purely genetic considerations regarding induction, many other factors can be correlated. Environmental factors (temperature, solar radiation, water availability), abiotic stress occurring before and during the bud differentiation stage, as well as some cultivation practices (pruning type and time, thinning, training systems, fertilization, irrigation, chemical observed where the $120 \%$ ETo level presented around $112 \mathrm{mg} \mathrm{g}^{-1}$, falling to $85 \mathrm{mg} \mathrm{g}^{-1}$ in the level with $60 \%$ ETo (Figure 4D).

The soluble protein reduction presented by plants under water stress was probably due to increased proteases enzymatic activity, since this enzyme promotes the breakdown of proteins and therefore decreases the protein presented in the plant under abiotic stress conditions (Taiz \& Zeiger, 2013).

For the flowering and fruiting variables evaluated there was significant effect of the interaction irrigation level and cultivars only for the fruit set parameter. The other variables showed significant effect of the isolated effects. Figure 5 contains variations for the cultivars regarding flowering and fruit set.

treatment have been identified as modulators of floral induction regulation and important causes able to modify flower differentiation phases (Neri et al., 2010).

Figure 5B shows that $\mathrm{Cv}$. Juliet had $\mathrm{a}$ higher percentage of shoots, but both cultivars presented acceptable values because, according to Oliveira et al. (2013b), for apple orchard development and its good formation under semiarid conditions, the sprouting index should approach $35.56 \%$ (a satisfactory value).

The fruit set percentage of $\mathrm{cv}$. Juliet (Figure $5 B$ ) is an indication of the high potential of $\mathrm{cv}$. Princess as a pollinator. According to Junior et al. (2010), cv. Princess presents optimum characteristics as a pollinating cultivar, by combining the number of anthers/flower, pollen grain count/ anther and pollen germination capacity at satisfactory levels. However, despite the low fruiting observed in this present work for 
the pollinator cv. Princess, Lopes et al. (2013a) found high potential in it regarding apple production in the semiarid climate.

The variable, fruit set, presented interaction between irrigation levels and cultivars. The variables NFL, NFR and shoot percentage

(SP) showed significant effects for irrigation levels (Figure 6). According to the regression analysis, the linear model was the best fit, with the highest irrigation depth (120\% ETo) providing, statistically, better response when compared to other treatments.
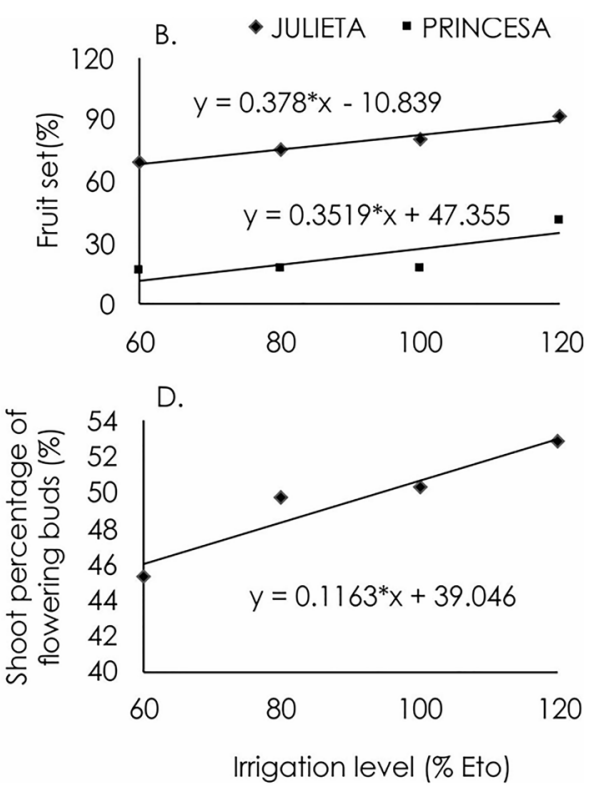

Figure 6. Fruit set (A) number of emitted flowers (B), number of fruits (C) and shoot percentage of flowering buds (D) of apple trees subjected to different irrigation levels.

The number of flowers (Figure 6A) and the number of fruits (Figure 6C) progressively increased with increased irrigation, thus demonstrating the direct influence of irrigation on the relationship between issued flowers produced and fruits produced.

In both cultivars evaluated, we observed that for the ratio between the fruit number and the number of flowers per branch (Figure 6B), the treatment whith greater water level $120 \%$ ETo) showed a better response, resulting in greater fruiting efficiency of apple trees, cv. Juliet being statistically superior. The least fruit set observed can be explained by the lower shoot percentage observed in cv. Princess (Figure 5B) and in the level with 60\% ETo (Figure 6D), where the conditions were not sufficient to promote good sprouting.

Figure 5D demonstrates the percentage of shoots increased in relation to irrigation level applied. This result confirms what was described by Fioravanço et al. (2012) who found that good water availability for apple trees provided good sprouting conditions.

\section{Conclusions}

Reducing irrigation during flowering increased carbohydrate content in apple leaves The apple varieties Juliet and Princess increase sprouting, flowering and fruit set with increasing irrigation levels.

The cv. Juliet provided a good fruit yield, one better than cv. Princess.

\section{References}

Alizadeh, A., Alizade, V., Nassery, L., Eivazi, A. 2011. Effect of drought stress on apple dwarf rootstocks. Technical Journal of Engineering and Applied Science 1: 86-94.

Borba, M.D.C., Scarpare Filho, J.A., Kluge, R.A. 2005. Teores de carboidratos em pessegueiros submetidos a diferentes intensidades de poda verde em clima tropical. Revista Brasileira de Fruticultura 27: 68-72.

Bradford, M.M. 1976. A rapid and sensitive method for the quantification of microgram quantities of protein utilizing the principle of protein-dye binding. Analytical Biochemistry 72: 248-258.

Cardoso, L.S. 2011. Modelagem aplicada à fenologia de macieiras 'Royal gala'e 'Fuji suprema'em função do clima, na região 
de Vacaria, RS. 166 f. (Tese de doutorado) Universidade Federal do Rio Grande Do Sul, Porto Alegre, Brasil.

Costa, R.C.L., Lobato, A.K.S., Oliveira Neto, C.F., Maia, P.S.P., Alves, G.A.R., Laughighouse IV, H.D. 2008. Biochemical and physiological responses in two Vigna unguiculata (L.) Walp. cultivars under water stress. Agronomy Journal 7: 98- 101.

Cruz, M.C.M., Siqueira, D.L., Salomão, L.C.C., Cecon, P.R., Santos, D. Dos. 2007. Teores de carboidratos em limeiras ácidas 'Tahiti' tratadas com paclobutrazol. Revista Brasileira de Fruticultura 29: 222-226.

Fioravanço, J.C., Czermainski, A.B.C, Alves, S.A.M. 2012. Condições meteorológicas e sua influência na safra de maçã de 2011/12 em Vacaria, RS. Embrapa Uva e Vinho, Bento Gonçalves, Brasil. 8p. (Comunicado Técnico).

Fioreze, S.L., Pivetta, L.G., Fano, A., Machado, F.R., Guimarães, V.F. 2011. Comportamento de genótipos de soja submetidos a déficit hídrico intenso em casa de vegetação. Revista Ceres 58: 342-349.

García-Tejero, I., Muriel-Fernández, J.L. 2011. Long-term impact of sustained-deficit irrigation on yield and fruit quality in sweet orange cv. Salustiana (SW Spain). Comunicata Scientiae 2: 76-84.

IBGE. Banco de dados agregados. 2014. Informações Estatísticas. http://www.ibge.gov. br. <Acesso em: 30.10.2014>.

Iuchi, V. L. 2006. Botânica e fisiologia. In: EPAGRI. A cultura da macieira. EPAGRI, Florianópolis, Brasil. p. 59-104.

Junior, C.L.D.A., Denardi, F., Dantas, A.C.D.M., Nodari, R.O. 2010. Número de anteras por flor, grãos de pólen por antera e capacidade germinativa do pólen de diferentes cultivares de macieiras. Revista Brasileira de Fruticultura 32: 1255-1260.

Kala, S., Godora, A.K. 2011. Effect of moisture stress on leaf total proteins, proline and free amino acid content in commercial cultivars of Ziziphus mauritiana. Journal of Scientific Research Banaras Hindu University 55: 65-69.

Kobayashi, E. S., Sakai, E., da Silva, E. A., Arruda, F. B., Silveira, J. M. D. C., de Souza, P. S., Pires, R. C. D. M. 2008. Variação sazonal do potencial da água nas folhas de cafeeiro em Mococa, SP. Bragantia 67: 421-428

Lopes, P.R.C., Oliveira, I.V.D.M., Abrantes, D.H. 2013b. Avanços na produção de frutas de clima temperado no Estado do Ceará. In Embrapa Semiárido-Artigo em anais de congresso (ALICE).
In: Semana Internacional da Fruticultura e Agroindústria, 20., Agroflores, 15., 2013. Fortaleza. Anais... Fortaleza: Instituto Frutal, 2013.

Lopes, P.R.C., Oliveira, I.V.D.M., Silva, R.R.S.D., Cavalcante, Í.H.L. 2013a. Growing Princesa apples under semiarid conditions in northeastern Brazil. Acta Scientiarum. Agronomy 35: 93-99.

Miranda, J.M. de S., Cavalcante, Í.H.L., Oliveira, I.V. de M., Lopes, P.R.C., Assis, J.S. de. 2015a. Fruit quality of 'Eva' e Princesa apples grown under nitrogen fertigation in semiarid climate. Revista Brasileira de Engenharia Agrícola e Ambiental 19: 967-972.

Miranda, J.M. de S., Cavalcante, Í.H.L., Oliveira, I.V. de M., Lopes, P.R.C. 2015b. Advances on apple production under semiarid climate: $\mathrm{N}$ fertigation. Emirates Journal of Food and Agriculture 27: 1-748.

Miller, E.L. 1959. Use of dinitrosalicylic and reagent determination of sugar. Analytical Chemistry 31: $426-428$.

Neri, D., Morini, F., Massetani, F., Pirazzini, P. 2010. Pruning: how to manage shoot growth. Acta Horticulturae 862: 355-363.

Oliveira, D.L., Cruz, M.D., Oliveira, A.F., Chalfun, N.N.J., Alvarenga, A.A. $2013 a$. Carbohydrates levels and induction of flowering in olive seedlings subjected to the application of paclobutrazol. Scientia Agraria Paranaensis 12: 221-226.

Oliveira, I.V.M., Lopes, P.R.C., Silva-Matos, R.R.S. 2013b. Caracterização fenológica e frutificação efetiva de macieiras 'daiane' sob condições semiáridas no nordeste do Brasil. Revista de Ciências Agroambientais 1 1: 153-158.

Peixoto, C.P., Cerqueira, E.C., Soares Filho, W.S., Castro Neto, M.T., Ledo, C.A.S., Matos, F.S., Oliveira, J.G. 2006. Análise de crescimento de diferentes genótipos de citros cultivados sob déficit hídrico. Revista Brasileira de Fruticultura 28: 439-443.

Prado, A.K.D.S., Machado, E.C., Medina, C.L., Machado, D.F.S.P., Mazzafera, P. 2007. Flowering and fruit set in'valência'orange trees under different crop load status and with and without irrigation. Bragantia 66: 173-182.

Ribeiro, R.V., Machado, R.S., Machado, E.C., Machado, D.F.S.P., Magalhães Filho, J.R., Landell, M.G.A. 2013. Revealing drought-resistance and productive patterns in sugarcane genotypes by evaluating both physiological responses and stalk yield. Experimental Agriculture 49: 212-224.

Santos, C.M.G., Moreira, M.M., Rodrigues, J.D. 2013. Metabolismo da videira 'syrah'no semiárido 
nordestino sob três estratégias hídricas. Semina: Ciências Agrárias 34: 3611-3624.

Silva, A.R.A., Bezerra, F.M.L., Lacerda, C.F., Pereira Filho, J.V., Freitas, C.A.S. 2013. Trocas gasosas em plantas de girassol submetidas à deficiência hídrica em diferentes estádios fenológicos. Revista Ciência Agronômica 44: 86-93.

Šircelj, H., Tausz, M., Grill, D., Batič, F. 2007. Detecting different levels of drought stress in apple trees (Malus domestica Borkh.) with selected biochemical and physiological parameters. Scientia Horticulturae 113: 362-369.

Sivaci, A. 2006. Seasonal changes of total carbohydrate contents in three varieties of apple (Malus sylvestris Miller) stem cuttings. Scientia Horticulturae 109: 234-327.

Taiz, L., Zeiger, E. 2013. Fisiologia Vegetal. 4 ed. Artmed, Porto Alegre, Brasil. 820 p.

Tomaz, Z.F.P., Lima, C.S.M., Gonçalves, M.A., Rufato, L., Rufato, A.D.R. 2010. Crescimento vegetativo, floração e frutificação efetiva do pessegueiro'Jubileu'submetido a diferentes comprimentos de interenxertos. Pesquisa Agropecuária Brasileira 45: 973-979.

Yemm, E.W., Willis, A.J. 1954. The estimation of carbohydrates in plant extracts by anthrona. The Biochemical Journal 57: 508-514. 